\title{
BREED PREFERENCES AND EFFECTIVENESS OF BEEKEEPING IN THE SOUTH URAL
}

\section{ПОРОДНЫЕ ПРЕДПОЧТЕНИЯ И ЭФФЕКТИВНОСТЬ ПЧЕЛОВОДСТВА НА ЮЖНОМ УРАЛЕ}

\section{A. Mashenkov, Post-graduate student}

А.М. Машенков, аспирант

\section{A. Glinushkin, Candidate of Biological Sciences}

А.П. Глинушкин, кандидат биологических наук

\author{
M. Mashenkov, Candidate of Agricultural Sciences \\ М.И. Машенков, кандидат сельскохозяйственных наук \\ Orenburg State Agrarian University, Orenburg, Russia \\ Оренбургский государственный аграрный университет \\ E-mail: glinale@gmail.com
}

Received December 8, 2012

\begin{abstract}
Efficiency of beekeeping is defined by breed of bees and melliferous herbs. In the conditions of sharply continental climate of South Ural, duration of success of beekeeping is provided with breed of bees.

\section{АННОТАЦИЯ}

Эффективность пчеловодства определяется породой пчел и медоносами. В условиях резко континентального климата Южсного Урала, длительность успеха пчеловодства обеспечивается породой пчел.
\end{abstract}

\section{KEY WORDS}

Breed; Bees; Honey plants; Climatic conditions.

КЛЮЧЕВЫЕ СЛОВА

Порода; Пчель; Медоносы; Климатические условия.

В настоящее время в мире насчитывается около 60 млн. пчелиных семей, дающих 500 тыс. т. меда, а кроме этого они собирают пыльцу, производят пергу, маточное молочко, прополис, яд - пчелиный, воск. В России по данным переписи 2006 г. около 5,3 млн. пчелиных семей. В Оренбуржье насчитывается 65,9 тыс. пчелиных семей (в каждой семье 50000-80000 особей), ежегодно производится 28,2-32,0 т. воска, 0,4 т. прополиса, 0,03-0,04 т. маточного молочка. В последние 10 лет в области производилось в среднем по 900 т. меда в год.

По данным Госкомстата Оренбургской области, объем производства меда составил в
2011 году около 940 т. Всю эту продукцию дают пчеловодческие предприятия всех форм собственности, среди которых, в среднем 86 $\%$ составляют любительские пасеки, $>13 \%$ сельскохозяйственные предприятия, <1 \% фермерские хозяйства.

Максимальный же размер пасек пчеловодов Оренбургской области 300 пчелосемей. Таких пасек насчитывается единицы. Это связано с тем, что хозяйства в своей деятельности почти не применяют интенсивные технологии содержания пчелиных семей, а производством пчелопродукции занимаются в основном хозяйства населения (к хозяйствам населения отнесены личные подсобные хо- 
зяйства населения, садовые и огородные земельные участки).

Основными источниками нектара для пчел наряду с естественными медоносами лугов лесостепных районов области являются сеяные энтомофильные культуры: эспарцет, донник, козлятник, люцерна, клевер, а также подсолнечник, гречиха, рапс, горчица.

В настоящее время гречиха является ведущей медоносной культурой среди посевных культур. В мире площади занятые этой культурой составляют около 1,6 млн. га, 80\% приходится на Россию. По медопродуктивности с 1 га она дает от 70 до 200 кг. Для эффективного опыления этой культуры требуется 2,5-3 пчелосемьи на 1 га.

В Оренбуржье площади под культурой гречихи составляет 129 тыс. га, следовательно, только для этой культуры необходимо 350-400 тыс. пчелосемей. К сожалению, реальное количество семей пчел в Оренбуржье не превышает 60-70 тыс., что приводит к потере 18 тыс. тонн первоклассного меда и недобору около 100 тыс. тонн урожая гречихи. Если учесть рыночную стоимость меда и гречихи, то упущенная выгода составляет около 6 млрд. рублей.

Материалы и методика исследований. Экспериментальные исследования проводились в 2000 - 2009 гг. В условиях лесостепной зоны Шарлыкского лесхоза на территории Константиновского сельского совета. В условиях степной зоны юго-восточной части Илекского района Оренбургской области.

Целью наших исследований была оценка биологических и хозяйственных показателей пчелиных семей различного породного происхождения, которая включала:

- сравнение экстерьера пчел разного породного происхождения;

- наблюдение за ростом и развитием семей в течении весенне-летнего периода;

- зимовка пчел и устойчивость к болезням и вредителям;

- оценка медопродуктивности пчел, в т.ч. от возрастного состояния маток.

Для этого были подобраны 4 группы пчел разного происхождения.

\section{РЕЗУЛЬТАТЫ И ИХ ОБСУЖДЕНИЕ}

Сравнительное испытание эффективности опыления культур гречихи показали, что при посеве в 3-ей декаде мая всходы появились 1-3 июля, Цветение началось 5-7 июля и продолжалось до 15-30 августа.

Пчелоопыление позволяет почти в 2 раза повысить урожай гречихи по сравнению с естественным опылением т. е. опыление ветром и одиночными насекомыми.

При отсутствии опыления насекомыми урожайность гречихи снижается на $30 \%$ по сравнению с естественным опылением и почти в 3 раза ниже, чем при пчелоопылении.

На территории области районированы среднерусская пчела башкирской популяции, приокская темнолесная порода, отличающаяся исключительной зимостойкостью. Эти пчелы уникальны - они могут жить в лесах, в дуплах деревьев, увеличивая площади медосбора. Все эти факторы способствуют тому, чтобы заниматься пчеловодством выгодно в промышленных масштабах.

Однако 2 из 5 семей пчел это метизированные пчелы, которые поступают в Оренбуржье из регионов Средней Азии: Киргизии, Узбекистана, Казахстана. Наиболее распространенный способ содержания пчел в зимний период в омшаниках с температурой от 0 до $+3^{0} \mathrm{C}$. Все породы и помеси, кроме среднерусских пчел не приспособлены к естественным условиям зимовке на воле.

Поэтому данная порода, учитывая длительный зимний период около 5,5 месяцев без облета наиболее перспективна для Оренбуржья. Для продвижения этой породы на пасеки необходимо развивать местное питомниководство (под эгидой Министерства сельского хозяйства), возможна поддержка со стороны тех пчеловодов, которые разводят эту породу. Необходимо так же ограничить ввоз на Южный Урал пород и тем более помесей, не приспособленных к суровому климату.

Наблюдения и характеристика признаков пчел разного происхождения позволяют сделать следующие обобщения: самые крупные особи пчел имеются у среднерусских пчел и узбекской популяции; трутни у узбекской популяции, затем среднерусской. Матки этих пчел отличаются высокой плодовитостью, специфическим цветом кутикулы.

Среднерусские пчелы: попадают на пасеки в результате закупки пакетов и маток у пчеловодов Башкирии. Местные пчелы с преобладанием Apica mellifera имеют признаки среднерусской пчелы: злобливы или умеренно 
- злобливы; зимостойкость хорошая; мелопродуктивность от 35 до 73 кг, (т.е. весьма не выравнена); воскопродуктивность хорошая (8$10)$, пчелы умеренно-устойчивы к нозематозу (2-3 балла); по зимостойкости от отличной зимостойкости до средней (6-10 баллов).

Среднерусские пчелы (из питомников Башкирии и Татарстана) характеризуются умеренной злобливостью, хорошей и отличной зимостойкостью, количество подмора не превышает 200 грамм, по сбору меда не уступает чистопородным семьям других пород и достигает 42-85 кг, печатка меда белая. Характеризуются устойчивой к нозематозу и высокой строительной деятельностью сотов 9-12 штук. Матки серого цвета с легкой желтизной.

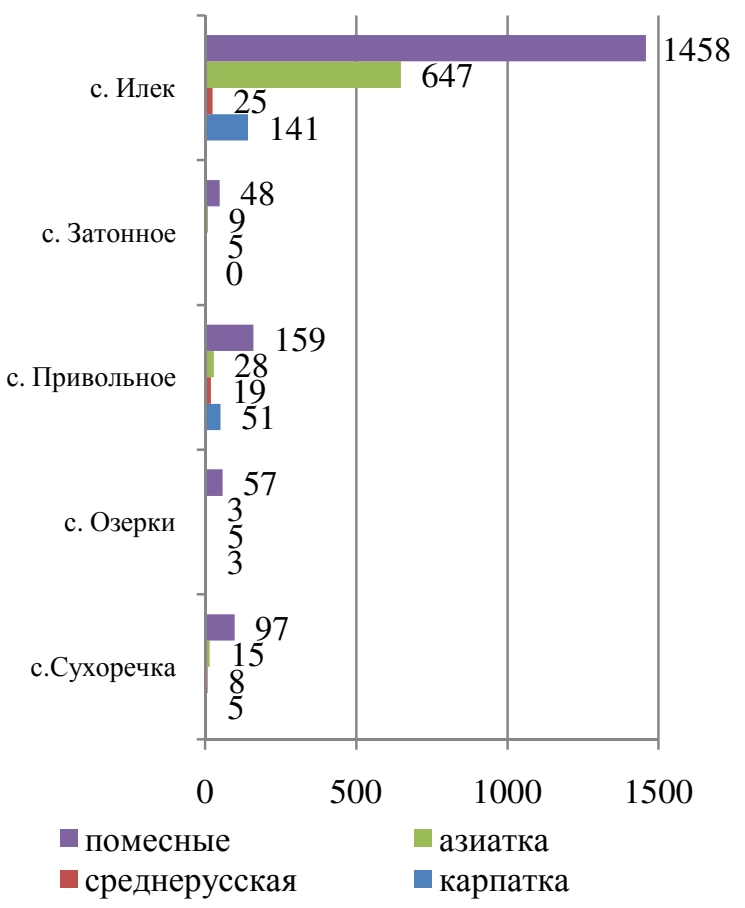

Рисунок 1 - Породы пчел имеющиеся в хозяйствах сёл Илекского района

Карпатская порода пчел (Apica carnica) характеризуется умеренной или слабой злобливостью, зимостойкость средняя, количество подмора зависит от способа зимовки и достигает 350-1200 г. Среднеустойчивы к нозематозу. Медопродуктивность этой породы пчел довольно хорошая от -35 до 90 кг. Карпатка характеризуется хорошей строительной деятельностью, отстраивая до 10 и более сотов на семью. Матки темной окраски. Рост семей умеренный.
Анализ показывает, что лидирующее положение по всем показателям имеют пчелы среднерусской и карпатской пород. По отдельным показателям лучше карпатка (миролюбие), по другим среднерусские пчелы (зимостойкость).

Исследование причин гибели пчел в зимний период и методов их устранения выявили группу основных причин приводящих пчел к гибели: - неправильный выбор породы и малый клуб пчел; - проникновение грызунов в улей; - опоношенность гнезда; - некачественный корм; - нехватка корма; - клещевые болезни; - нарушение микроклимата в гнезде (в том числе и температурно-влажностного режима); несоответствие породы (условиям подготовки к зиме и зимовью); - нарушение технологии (содержания пчел); - иные причины. Среди выявленных причин гибели доминирует: 1 . Несоответствие пород пчел; 2. Нарушение технологии содержания и нозематоз; 3. Нехватка корма, 4. Варроагоэ; 5. Некачественный корм.

\section{ВЫВОДЫ}

1. Семьи пчел с чистопородными матками превосходят медопродуктивностью семьи местных популяций пчел на 30-109\%.

2. Семьи пчел с чистопородными матками по основным хозяйственным показателям: ройливости, злобливости, зимостойкости превосходят местную популяцию пчел, так ройливость их не превышает $16 \%$ и вследствие сбалансированности наследственной основы злобливостъ семей умеренная и не превышает 6,5 баллов, наличие нозематоза не более $14 \%$.

3. С целью: улучшения зимовки и зимостойкости семей пчел Apica mellifera целесообразно оставлять в зиму семьи силой 2-3 кг или 8-12 улочек, в этом случае количество подмора минимально 0,4-0,6 кг, а сохранность семей достигает $100 \%$.

4.Среди основных причин гибели семей пчел и большого количества подмора является нарушение технологии содержания, среди которых решающее условие сохранности: сила семей 8-12 улочек пчел, достаточное наличие кормовых запасов 20-25 кг, лечение пчел перед зимовкой от болезней, отсутствие сквозняков и наличие заградителей от мышей. Главное место в сохранности семей при зимовке пчел на воле предпочтение отдавать среднерусской породе. 
5. Для выявления породного происхождения пчел необходимо знать основные экстерьерные признаки разных пород пчел, среди которых решающим является кубитальный индекс.

6. Сравнительное испытание пчел разного породного происхождения показало существенное преимущество чистопородных семей пчел: среднерусской и карпатской пород по основным хозяйственным показателям: сбору меда и восковой деятельности на 29-60\% по сравнению с помесными пчелами.

7. Правильная организация гнезда (на территории Константиновского сельского совета), когда клуб полностью перекрывает площадь поверхности гнезда, гибель пчел и появление подмора не наблюдается, при содержании любой породы в зимний период.

\section{БИБЛИОГРАФИЯ}

Бей-Биенко Г.Я. Общая энтомология: Учебник для университетов и $\mathrm{c} / \mathrm{x}$ вузов.- М.: Высшая школа, 1980. - 416 с.

Плавильщиков Н.Н. Определитель насекомых, М.: Топикал. 1994. - 544 с. ил.

Херольд Э. Новый курс пчеловодства, М.: АСТ- Астрель, 2007. - 368 с, ил.

Белик Э.В. Большой современный справочник пчеловодства: Донецк, 2004. - 544c.
Туктаров В.Р., Мишуковская Г.С. Таксономический статус клеща VARROA и влияние степени заклещеванности пчелиных семей на экстерьерные показатели рабочих пчел APIS MELLIFERA L. //Вестник БГАУ. - №3. - 2012. С. 46-49. 